\title{
Editorial
}

\section{0 parto é meu: resgatando o protagonismo da mulher}

O cenário atual no Brasil sobre parto e nascimento aponta para índices de cirurgia cesariana bem acima do que o recomendado pela Organização Mundial de Saúde. Estes dados vêm assinalando para a necessidade de um novo modelo na assistência ao processo de parturição que considere o contexto social, cultural, humano e de gênero, respeitando o protagonismo da mulher e a fisiologia do parto.

O nascimento de forma natural de um bebê saudável está entre as experiências mais intensas na vida de uma mulher e da família em formação. A vivência positiva desse momento, a qualidade da assistência prestada/recebida no decorrer da gestação, parto e nascimento podem ter efeitos significativos e duradouros sobre a vida da mãe e do bebê. Este extraordinário momento deve envolver assistência humanizada que se fundamente no respeito, na segurança, na dignidade e autonomia das mulheres e das famílias.

O grande desafio está no fortalecimento e consolidação de políticas públicas que sistematizem e institucionalizem um modelo de atenção ao parto e ao nascimento, que vem sendo discutido e construído no país, desde a década de oitenta, com base no pioneirismo e na experiência de médicos e enfermeiras obstetras, obstetrizes, parteiras, doulas, gestantes, grupos feministas, ativistas dentre muitos outros, vislumbrando o resgate do protagonismo da mulher na vivência ao parto e nascimento. Incluindo a ambiência adequada para a boa evolução do nascimento do bebê, com a inclusão da presença de um acompanhante de livre escolha da mulher ${ }^{1}$, além da adoção de boas práticas de atenção centradas no bem-estar da mulher, da criança, do pai e da família, associada às ações de melhoria da eficiência gestora dos serviços de saúde.

0 profissional da saúde inserido na assistência à gestante e sua família, deve pautar sua conduta no atendimento centrado na pessoa, buscando compreender os significados de sua gestação. Neste panorama, o enfermeiro, pela natureza da sua formação voltada para o cuidar, abarca potencialidades múltiplas para atuar neste processo.

Para suprir esta demanda de mudança de modelo assistencial, a formação de enfermeiros obstetras, para a assistência à mulher no período grávido-puerperal e do recém-nascido de risco habitual, vem sendo alvo de políticas governamentais nos últimos anos, buscando retratar a experiência de países desenvolvidos, onde as parteiras profissionais são as provedoras da atenção primária à saúde de mulheres saudáveis durante o parto.

É necessário compreender e respeitar a mulher grávida, a oferecer para a parturiente o que lhe traz segurança e conforto ao ponto de liberar os seus instintos primitivos ${ }^{2}$, o que fazem com maestria as parteiras e enfermeiras obstetras.

O cérebro secreta hormônios que participam do parto, particularmente a parte profunda, primitiva do cérebro que são compartilhadas com outros mamíferos. 0 hipotálamo, assim como as glândulas trabalham secretando hormônios, que estimulam e favorecem o desenvolvimento natural e fisiológico do parto. Portanto, as inibições que acontecem durante o trabalho de parto estão ligadas ao cérebro alto, o córtex que somente os seres humanos têm, o neocórtex, aqui está a chave de tudo.

Para resgatar o protagonismo da mulher no processo de parturição é necessário garantir ambiência propícia à estimulação primitiva de hormônios e ajudar a mulher a entrar em contato consigo mesma e criar a própria ocitocina e endorfinas, essenciais para o bom percurso do parto.

Está se falando da "cientificação do amor". Portanto, as enfermeiras obstetras e demais profissionais devem favorecer o encontro da mulher com sua corporeidade abolindo as intervenções desnecessárias, devolvendo a autonomia a quem de direito, o parto é da mulher, o protagonismo é dela.

\section{Referências}

1.Brasil. Lei n 11.108, de 7 de abril de 2005. Altera a Lei no 8.080, de 19 de setembro de 1990, para garantir às parturientes o direito à presença de acompanhante durante o trabalho de parto, parto e pós-parto imediato, no âmbito do Sistema Único de Saúde - SUS. Diário Oficial da União [internet]. Brasília; 2005 [citado 3 Abr 2019]. Disponível em: http://www3.dataprev.gov.br/sislex/paginas/42/2005/11108.htm

2. Odent M. Birth under water. The Lancet 24:31, 1983.

3. Sabatino H. Atenção ao nascimento humanizado baseado em evidências científicas: paradigmas do nascimento, Manaus, 2014, v. 3.

Boa leitura!

Efigênia Aparecida Maciel de Freitas

Enfermeira. Especialista em Enfermagem Obstétrica. Especialista em Saúde Pública. Mestre em Ciências da Saúde. Doutora em Enfermagem Psiquiátrica. Professora da Faculdade de Medicina da Universidade Federal de Uberlândia (UFU). 